\title{
Does the optimization of intra-operative cerebral regional oxygen saturation have an effect on neurological function in elderly patients undergoing cardiac surgery?
}

\author{
Ewa Kucewicz' ${ }^{1}$ Sławomir Żegleń ${ }^{2}$, Jacek Wojarski², Jan Głowacki², Jarosław Borkowski J'1, \\ Konrad Leśniak ${ }^{1}$, Ewa Podwińska ${ }^{3}$, Katarzyna Skuza ${ }^{1}$, Agata Puzio ${ }^{4}$, Roman Przybylski² \\ ${ }^{1}$ Clinical Department of Cardiac Anesthesia and Intensive Care, Medical University of Silesia, Silesian Center for Heart Diseases \\ in Zabrze \\ ${ }^{2}$ Chair and Clinical Department of Cardiac Surgery and Transplantology, Medical University of Silesia, Silesian Center for Heart \\ Diseases in Zabrze \\ ${ }^{3}$ Chair of Anesthesiology, Intensive Care, and Emergency Medicine, Medical University of Silesia \\ ${ }^{4}$ Student Research Group at the Clinical Department of Cardiac Anesthesia and Intensive Care, Medical University of Silesia, \\ Silesian Center for Heart Diseases in Zabrze
}

Kardiochirurgia i Torakochirurgia Polska 2013; 10 (4): 380-388

\begin{abstract}
Background: The optimization of cerebral oxygen delivery variables by using noninvasive cerebral oximetry could reduce the incidence of stroke.

The aim of the study was to evaluate the effect of the intraoperative management of oxygen delivery on neurological function during the early postoperative period in elderly patients undergoing cardiac surgery.

Material and methods: This observational study included 257 patients, aged 75 and above, who underwent surgery in 2011. In the study group (119 patients), cerebral oxygen saturation was monitored and managed in order to maintain the oximetry values within individually assigned optimal levels. The control group (138 patients) underwent cardiac surgery without the intraoperative monitoring of cerebral oximetry. The two groups were dissimilar with regard to age, EuroSCORE risk factors, previous cerebral vascular accidents, and chronic kidney disease. More patients in the control group had preoperative NYHA class I.

Results: There was no difference between the groups with regard to the incidence of permanent stroke. Total ventilation time was significantly shorter in the study group. Patients in the study group required shorter lung ventilation and a lower number of packed red blood cell units. The length of postoperative ward and hospital stay was longer among the patients with low values of baseline cerebral oximetry $(<50 \%)$.

Conclusions: These findings suggest that intraoperative patient management based on cerebral oxygen monitoring may
\end{abstract}

\section{Streszczenie}

Wstęp: W celu ograniczenia częstości występowania powikłań neurologicznych po operacjach kardiochirurgicznych podejmowane są różne działania. Należy do nich śródoperacyjne monitorowanie funkcji ośrodkowego układu nerwowego (OUN). Celem pracy była ocena wpływu utrzymywania regionalnej saturacji mózgowej w wyznaczonych granicach na częstość występowania powikłań neurologicznych typu I we wczesnym okresie pooperacyjnym $u$ chorych $w$ wieku $\geq 75$ lat poddawanych zabiegom kardiochirurgicznym. Analizowano także częstość występowania innych powikłań w obu grupach.

Materiat i metody: Do grupy badanej zakwalifikowano pacjentów operowanych w 2011 r., u których śródoperacyjnie monitorowano oksymetrię mózgową i utrzymywano jej wartość na optymalnym, indywidualnie wyznaczonym poziomie. Grupę kontrolną stanowili chorzy, u których zrezygnowano z monitorowania $\mathrm{ScO}_{2}$. Do badań włączono chorych $\geq 75$. roku życia. Grupa badana liczyła 119, kontrolna 138 chorych. Do monitorowania $\mathrm{ScO}_{2}$ wykorzystano metodę spektroskopii w widmie bliskim podczerwieni.

Wyniki: Chorzy w grupie monitorowania $\mathrm{ScO}_{2}$ byli znamiennie starsi i w tej grupie częściej odnotowano przebyty udar OUN. Mimo to wczesne udary pooperacyjne wystąpity z tą samą częstością w obu grupach. Chorzy w grupie badanej charakteryzowali się w okresie pooperacyjnym krótszym czasem wentylacji płuc i mniejszą liczbą przetoczonych jednostek koncentratu krwinek czerwonych, mimo że w grupie kontrolnej więcej chorych sklasyfikowano w I grupie wydolności wg NYHA. Pacjenci 
improve the postoperative course in elderly patients after cardiac surgery.

Key words: elderly patients, cerebral oximetry, cardiac surgery. z grupy badanej częściej obciążeni byli współistniejącą przewlekłą niewydolnością nerek, co pozostawało bez wpływu na częstość stosowania terapii nerkozastępczej w okresie pooperacyjnym. Pacjenci z niską wyjściową saturacją mózgową dłużej przebywali na oddziale pooperacyjnym i dłuższy był czas ich hospitalizacji.

Wnioski: W obu grupach częstość występowania powikłań neurologicznych typu I była podobna. Uzyskane wyniki uzasadniają stwierdzenie, że śródoperacyjne utrzymywanie $\mathrm{ScO}_{2}$ na optymalnym poziomie działa protekcyjnie na funkcję narządów we wczesnym okresie pooperacyjnym.

Słowa kluczowe: pacjenci w zaawansowanym wieku, oksymetria mózgowa, zabiegi kardiochirurgiczne.

outside the hospital [6]. Neurological complications are most often encountered in patients treated at departments of cardiology, cardiac surgery, and vascular therapy. Invasive procedures, such as cardiac surgery and intravascular interventions, are the most frequent cause of intrahospital strokes [7]. Mortality is high in this patient group, as it exceeds $18 \%$, and the cause of death is the stroke itself or its consequences, often without any relation to the disorders for which the patient was admitted to the hospital [6].

Neurological complications may also prevent the successful surgical treatment of heart diseases. Various measures are being taken in order to limit their incidence. Among them is the intraoperative monitoring of CNS function. The method used in the present study was the monitoring of regional hemoglobin oxygen saturation, measured in the frontal lobes in the brain.

The aim of the study was to evaluate the influence of maintaining regional cerebral saturation within ranges established individually for each patient on the incidence of type I neurological complications during the early postoperative period in patients aged $\geq 75$ years undergoing cardiac surgery procedures. Other postoperative complications were also analyzed.

\section{Material and methods}

This work is an observational study, approved by the Bioethics Committee of the Medical University of Silesia (MUS) in Katowice. Decisions concerning the intraoperative use of $\mathrm{ScO}_{2}$ (cerebral hemoglobin oxygen saturation) monitoring were made by a specialist anesthesiologist, responsible for providing anesthesia.

The study group included patients undergoing surgery at the Clinic of Cardiac Surgery and Transplantology of MUS in the year 2011, in whom cerebral oximetry was monitored intraoperatively in order to react to cases of desaturation with measures aimed at maintaining saturation at the optimal, individually assigned level. The control group consisted of patients in whom $\mathrm{ScO}_{2}$ monitoring was not employed. Only patients older than 75 years of age were included in the study, which encompassed 261 patients in total. Four patients were excluded from the analysis because of incomplete oximetry records. The study group ultimately 
comprised 119 patients, and the control group 138 patients. Preoperative group data are presented in Table I.

$\mathrm{SCO}_{2}$ monitoring was conducted using near-infrared spectroscopy (NIRS). The monitoring scheme and the rules for reacting to desaturation were presented in an article published in 2011 [8]. Desaturation time was calculated as the total of the two brain hemispheres. Total desaturation time, i.e. the total duration of saturation below $50 \%$, was calculated in seconds.

Within the study group, a separate patient subgroup was created, consisting of patients in whom the value of initial saturation was less than 50\% (16 patients). Patients with initial saturation $<50 \%$ were of significantly lower height; more of them suffered from unstable coronary artery disease (51.5\% vs. $81.3 \%$ ), and more of them underwent procedures using extracorporeal circulation $(44.7 \%$ vs. $75 \%)$.

All procedures were conducted under general anesthesia. Anesthesia was induced by administering etomidate, sufentanil, and rocuronium. The maintenance of anesthesia was achieved by infusions of sufentanil and propofol, as well as periodic inhalations of sevoflurane. Pulse oximetry, ECG, direct arterial blood pressure measurements, and central venous pressure were monitored continuously. In some patients, cardiac output was monitored continuously as well using thermodilution measurements (on the decision of the attending anesthesiologist).

In patients undergoing off-pump surgery for ischemic heart disease, $2 \mathrm{mg} / \mathrm{kg}$ heparin was administered, while patients requiring extracorporeal perfusion received a heparin dose of $3 \mathrm{mg} / \mathrm{kg}$.

Extracorporeal circulation was conducted in moderate hypothermia. Blood cardioplegia was used in a ratio of $1: 4$. Pressure was maintained within the range of 50-70 $\mathrm{mm} \mathrm{Hg}$; in some patients, this required the administration of nitroglycerin or norepinephrine. Hematocrit level was maintained at 25-29\%. Gasometry was conducted in accordance with the $\alpha$-stat principle. The effects of heparin were reversed by administering protamine sulfate.

The data concerning the type and mode of surgery, extracorporeal circulation time, and aortic clamping time are presented in Table II. The data include both the study group and the control group (Table II).

The presented data also include the subgroup of patients with baseline saturation $<50 \%$ (Table III). Procedures using extracorporeal circulation were performed significantly more often in patients with low baseline CNS saturation.

The following complications were noted during the postoperative period:

Low cardiac output syndrome was diagnosed in cases in which the use of more than one catecholamine was required, or if the cardiac index was lower than $2.4 \mathrm{l} / \mathrm{m}^{2}$ of body area in patients in whom hemodynamic monitoring involved the use of a Swan-Ganz catheter.

Postoperative bleeding was defined as the necessity of reoperation due to drainage from the postoperative wound.
Tab. I. Demographic data and preoperative condition of both patient groups

\begin{tabular}{|c|c|c|c|c|c|c|}
\hline & \multicolumn{5}{|c|}{$\mathrm{ScO}_{2}$ monitoring } \\
\hline & & \multicolumn{2}{|c|}{ No $(n=138)$} & \multicolumn{2}{|c|}{ Yes $(n=119)$} & \multirow[t]{2}{*}{$p$} \\
\hline & & Mean & St. dev. & Mean & $\begin{array}{l}\text { St. } \\
\text { dev. }\end{array}$ & \\
\hline \multicolumn{2}{|l|}{ Age } & 77.67 & \pm 2.96 & 78.65 & \pm 2.63 & 0.0003 \\
\hline \multicolumn{2}{|c|}{ Female gender } & 71 & $51.5 \%$ & 55 & $46.2 \%$ & 0.477 \\
\hline \multicolumn{2}{|l|}{ Weight } & 76.07 & \pm 13.03 & 75.11 & \pm 12.20 & 0.556 \\
\hline \multicolumn{2}{|l|}{ Height } & 163.90 & \pm 8.95 & 165.31 & \pm 9.10 & 0.134 \\
\hline \multicolumn{2}{|l|}{ BMI } & 28.23 & \pm 4.33 & 27.53 & \pm 3.89 & 0.089 \\
\hline \multicolumn{2}{|c|}{ EuroSCORE } & 7.19 & \pm 1.98 & 7.97 & \pm 2.29 & 0.004 \\
\hline \multicolumn{2}{|l|}{$\mathrm{EF}$} & 50.71 & \pm 9.32 & 48.40 & \pm 9.52 & 0.053 \\
\hline \multirow[t]{4}{*}{ CCS } & 1 & 30 & $22.2 \%$ & 25 & $21.6 \%$ & 0.992 \\
\hline & 2 & 43 & $31.9 \%$ & 38 & $32.8 \%$ & 0.999 \\
\hline & 3 & 46 & $34.1 \%$ & 35 & $30.2 \%$ & 0.589 \\
\hline & 4 & 16 & $11.9 \%$ & 18 & $15.5 \%$ & 0.517 \\
\hline \multirow[t]{4}{*}{ NYHA } & 1 & 36 & $26.3 \%$ & 17 & $14.3 \%$ & 0.029 \\
\hline & 2 & 68 & $49.6 \%$ & 59 & $49.6 \%$ & 0.939 \\
\hline & 3 & 28 & $20.4 \%$ & 37 & $31.1 \%$ & 0.065 \\
\hline & 4 & 5 & $3.7 \%$ & 6 & $5.0 \%$ & 0.802 \\
\hline \multicolumn{2}{|c|}{$\begin{array}{l}\text { Unstable disease } \\
\text { course }\end{array}$} & 85 & $61.6 \%$ & 66 & $55.5 \%$ & 0.385 \\
\hline \multicolumn{2}{|c|}{$\begin{array}{l}\text { Previous infarction } \\
<90 \text { days }\end{array}$} & 21 & $15.2 \%$ & 27 & $22.7 \%$ & 0.170 \\
\hline \multicolumn{2}{|c|}{ Cardiogenic shock } & 0 & $0.0 \%$ & 1 & $0.8 \%$ & 0.941 \\
\hline \multicolumn{2}{|c|}{$\begin{array}{l}\text { IABP (mechanical } \\
\text { support) }\end{array}$} & 0 & $0.0 \%$ & 1 & $0.8 \%$ & 0.941 \\
\hline \multicolumn{2}{|c|}{ Previous PTCA/stent } & 37 & $26.8 \%$ & 30 & $25.2 \%$ & 0.881 \\
\hline \multicolumn{2}{|c|}{ Arterial hypertension } & 109 & $79.0 \%$ & 99 & $83.2 \%$ & 0.486 \\
\hline \multicolumn{2}{|c|}{ Diabetes } & 57 & $41.3 \%$ & 46 & $38.7 \%$ & 0.761 \\
\hline \multicolumn{2}{|c|}{ CKD (creatinine > 200) } & 15 & $10.9 \%$ & 26 & $21.9 \%$ & 0.026 \\
\hline \multicolumn{2}{|c|}{$\begin{array}{l}\text { Carotid arterial athe- } \\
\text { rosclerosis }\end{array}$} & 12 & $8.7 \%$ & 16 & $13.5 \%$ & 0.309 \\
\hline \multicolumn{2}{|c|}{ Previous CNS stroke } & 4 & $2.9 \%$ & 12 & $10.1 \%$ & 0.034 \\
\hline \multicolumn{2}{|c|}{$\begin{array}{l}\text { Peripheral vascular } \\
\text { atherosclerosis }\end{array}$} & 13 & $9.4 \%$ & 16 & $13.5 \%$ & 0.413 \\
\hline
\end{tabular}

BMI - body mass index, EuroSCORE-European System for Cardiac Operative Risk Evaluation, EF - left ventricular ejection fraction in \% calculated echocardiographically, CCS - grading scale of angina pectoris, NYHA - grading scale for the extent of circulatory insufficiency, IABP - intra-aortic balloon pump, CKD chronic kidney disease, CNS - central nervous system

The number of packed red blood cells units administered during the patients' stay in the postoperative ward was recorded.

Reoperation was defined as the necessity of resternotomy due to bleeding, tamponade, or heart failure refractory to pharmacotherapy on the day of the surgery, or during the first postoperative 24 hours.

The time of mechanical pulmonary ventilation, as well as the necessity of reintubation and tracheostomy, was 
Tab. II. Type and mode of surgery conducted in the two groups

\begin{tabular}{|c|c|c|c|c|c|c|}
\hline \multirow{4}{*}{ OPCAB/MIDCAB } & & \multicolumn{5}{|c|}{$\mathrm{ScO}_{2}$ monitoring } \\
\hline & & \multirow{2}{*}{\multicolumn{2}{|c|}{$\begin{array}{c}\text { No } \\
(n=138)\end{array}$}} & \multirow{2}{*}{\multicolumn{2}{|c|}{$\begin{array}{c}\text { Yes } \\
(n=119)\end{array}$}} & \multirow{3}{*}{$\begin{array}{c}p \\
0.758\end{array}$} \\
\hline & & & & & & \\
\hline & & 67 & $48.6 \%$ & 61 & $51.3 \%$ & \\
\hline \multicolumn{2}{|l|}{ CABG } & 8 & $5.8 \%$ & 4 & $3.4 \%$ & 0.531 \\
\hline \multicolumn{2}{|l|}{ Valves } & 36 & $26.1 \%$ & 38 & $31.9 \%$ & 0.371 \\
\hline \multicolumn{2}{|l|}{ Complex } & 27 & $19.6 \%$ & 16 & $13.5 \%$ & 0.253 \\
\hline \multicolumn{2}{|l|}{ Unplanned surgery mode } & 55 & $39.9 \%$ & 61 & $51.3 \%$ & 0.088 \\
\hline Circulation time (min) & $n=71 / 58$ & 120.41 & 44.23 & 115.83 & 47.91 & 0.394 \\
\hline Clamp time (min) & $n=71 / 58$ & 77.31 & 33.51 & 73.24 & 29.57 & 0.194 \\
\hline
\end{tabular}

$O P C A B$ - off-pump coronary artery bypass, MIDCAB - minimally invasive direct coronary artery bypass, CABG - coronary artery bypass grafting

Tab. III. Type and mode of surgery conducted in the study group and the subgroup of patients with baseline saturation below $50 \%$

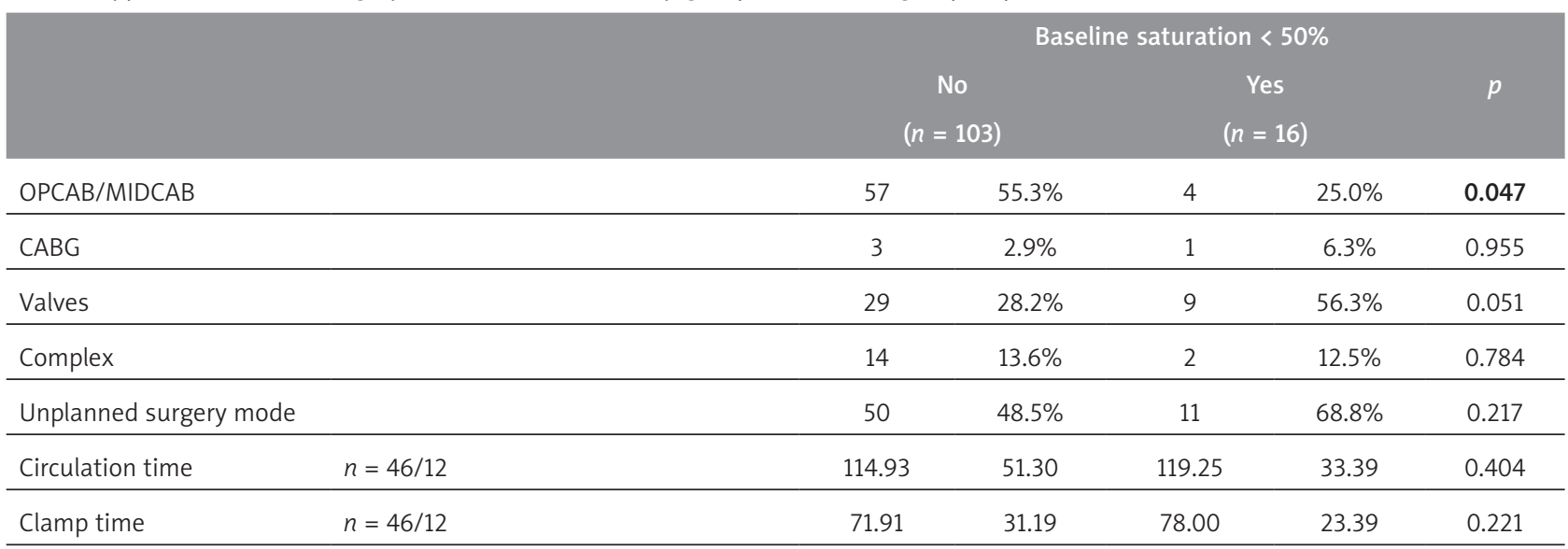

$O P C A B$ - off-pump coronary artery bypass, MIDCAB - minimally invasive direct coronary artery bypass, CABG - coronary artery bypass grafting

evaluated. Acute renal failure was diagnosed in patients in whom the use of renal replacement therapy was required.

Bleeding from the gastrointestinal tract, acute intestinal ischemia, liver failure, and acute cholecystitis were qualified as complications of the gastrointestinal tract.

The assessment included only type I neurological complications. The patients were diagnosed based on neurological examination, which was later verified by computed tomography. The incidence of delirium was not analyzed, because tools that would allow for the diagnosis of hypoactive or mixed delirium were not used.

The mortality analyzed in the study was defined as intrahospital death occurring within 30 days after the procedure.

\section{Statistical analysis}

As the studied quantitative variables were not in accordance with normal distribution, the non-parametric MannWhitney $U$ test was used for finding possible differences between the groups. Qualitative variables were analyzed with Yates' $\chi^{2}$ test. In order to determine the differentiation properties for the duration of intraoperative cerebral desaturations, ROC (receiver operating characteristic) analy- sis was performed. In order to determine the optimal cutoff point, equal costs of misclassification were assumed.

The data in the tables are presented as mean and standard deviation for quantitative variables or as amounts and percentages for fractions.

The value of $p<0.05$ was considered as statistically significant for the purposes of the whole analysis. All calculations were performed using the statistical software package Statistica v10.0 by StatSoft (StatSoft, Inc., Tulsa, USA).

\section{Results}

Low cardiac output syndrome was diagnosed in $40.3 \%$ of patients in the study group and $38.4 \%$ of patients in the control group. The incidence of the syndrome did not differ between the groups. In both groups, low cardiac output syndrome occurred significantly more often in patients undergoing surgery with the use of extracorporeal circulation ( $p$ < 0.001). The necessity of using adrenaline at a dose of more than $0.1 \mu \mathrm{g} / \mathrm{kg} / \mathrm{min}$ and noradrenaline did not differ between the groups. In both groups, mechanical cardiac support with the use of intra-aortic balloons was employed with the same frequency. 
Postoperative bleeding from the operated site occurred in $9.4 \%$ of controls and $4.2 \%$ of study group patients; statistical significance between the groups was not achieved. The total number of units of packed red blood cells ( $u$ pRBC) transfused during the stay at the postoperative ward was significantly higher in the control group (3.79 u pRBC/patient) than in the study group (2.44 u pRBC/patient).

Sixteen patients from the control group (11.6\%) and 9 patients from the study group $(7.5 \%)$ required reoperation, which does not constitute a statistically significant difference.

Patients from the control group required significantly longer mechanical ventilation; statistical significance was calculated as $p=0.014$. No patients from the study group required reintubation. The necessity of reintroducing ventilation therapy was noted in 6 patients from the control group. There was no statistically significant difference with regard to the frequency of reintubation in the two groups. Tracheostomy was performed in 2 patients in the control group, whereas no patients from the study group required this procedure. The frequency of performing tracheostomy in the two groups did not achieve statistical significance. In all cases, the reason behind the necessity of reintroducing mechanical lung ventilation was respiratory failure of various etiology.

Renal replacement therapy was used in 4 patients from the control group and 1 patient from the study group.
The frequency of employing renal replacement therapy did not differ between the groups.

One patient in the control group suffered from an abdominal complication in the form of paralytic ileus resulting from uremic syndrome.

Type I neurological complications were observed in 7 patients from the control group and 6 patients from the study group. All complications were ischemic strokes. The incidence of this complication was similar in both groups (Table IV).

The length of postoperative ward stay and the length of hospital stay did not differ between the groups. Mortality in the two groups was also similar: $2.2 \%$ in the control group and $0.8 \%$ in the study group (Table V).

Within the study group, a separate patient subgroup was created, consisting of patients with baseline regional CNS saturation lower than $50 \%$. The patients with cerebral saturation below $50 \%$ received more units of $\mathrm{pRBC}$ during the procedure and during their hospitalization. The incidence of particular complications and total complications did not differ between the subgroup of patients with baseline saturation below $50 \%$ and the study group (Table VI).

The patients with baseline cerebral saturation $<50 \%$ required significantly longer stays at the postoperative ward and the hospital (Table VII).

Tab. IV. Incidence of complications in both monitored groups

\begin{tabular}{|c|c|c|c|c|c|}
\hline \multirow{4}{*}{ Low cardiac output syndrome } & \multicolumn{5}{|c|}{$\mathrm{ScO}_{2}$ monitoring } \\
\hline & \multirow{2}{*}{\multicolumn{2}{|c|}{$\begin{array}{c}\text { No } \\
(n=138)\end{array}$}} & \multirow{2}{*}{\multicolumn{2}{|c|}{$\begin{array}{c}\text { Yes } \\
(n=119)\end{array}$}} & \multirow{3}{*}{$\begin{array}{c}p \\
0.851\end{array}$} \\
\hline & & & & & \\
\hline & 53 & $38.4 \%$ & 48 & $40.3 \%$ & \\
\hline Adrenaline > 0.1 & 4 & $2.9 \%$ & 7 & $5.9 \%$ & 0.385 \\
\hline Levonor & 25 & $18.1 \%$ & 18 & $15.1 \%$ & 0.636 \\
\hline IABP & 4 & $2.9 \%$ & 4 & $3.4 \%$ & 0.883 \\
\hline Bleeding & 13 & $9.4 \%$ & 5 & $4.2 \%$ & 0.165 \\
\hline pRBC administered intraoperatively & 1.14 & 1.72 & 1.04 & 1.55 & 0.165 \\
\hline pRBC outside the operating theater & 2.51 & 3.88 & 1.86 & 1.93 & 0.698 \\
\hline pRBC total & 3.64 & 5.14 & 2.90 & 2.86 & 0.855 \\
\hline Reoperation & 16 & $11.6 \%$ & 9 & $7.5 \%$ & 0.322 \\
\hline Ventilation time & 13.44 & 22.32 & 9.89 & 12.86 & 0.014 \\
\hline Reintubation & 6 & $4.4 \%$ & 0 & $0.0 \%$ & 0.059 \\
\hline Tracheostomy & 2 & $1.5 \%$ & 0 & $0.0 \%$ & 0.544 \\
\hline Renal replacement therapy & 4 & $2.9 \%$ & 1 & $0.8 \%$ & 0.460 \\
\hline Abdominal complications & 1 & $0.7 \%$ & 0 & $0.0 \%$ & 0.941 \\
\hline Neurological complications & 7 & $5.1 \%$ & 6 & $5.0 \%$ & 0.784 \\
\hline Total complications & 15 & $10.9 \%$ & 14 & $11.8 \%$ & 0.977 \\
\hline
\end{tabular}

Type I neurological complications were included.

$I A B P$ - intra-aortic balloon pump, $p R B C-1$ unit of packed red blood cells 
Tab. V. Length of postoperative ward stay, length of hospital stay, mortality

\begin{tabular}{|c|c|c|c|c|c|}
\hline \multirow{4}{*}{ Length of postoperative ward stay } & \multicolumn{5}{|c|}{ INVOS monitoring } \\
\hline & \multirow{2}{*}{\multicolumn{2}{|c|}{$\begin{array}{c}\text { No } \\
(n=138)\end{array}$}} & \multirow{2}{*}{\multicolumn{2}{|c|}{$\begin{array}{c}\text { Yes } \\
(n=119)\end{array}$}} & \multirow{3}{*}{$\begin{array}{c}p \\
0.286\end{array}$} \\
\hline & & & & & \\
\hline & 2.77 & 3.26 & 2.50 & 3.18 & \\
\hline Length of hospital stay & 10.80 & 9.27 & 10.77 & 8.48 & 0.764 \\
\hline Mortality & 3 & $2.2 \%$ & 1 & $0.8 \%$ & 0.722 \\
\hline
\end{tabular}

Tab. VI. Incidence of complications among patients with baseline saturation below 50\%

\begin{tabular}{|c|c|c|c|c|c|}
\hline \multirow[b]{4}{*}{ Low cardiac output syndrome } & \multicolumn{5}{|c|}{ Baseline saturation < $50 \%$} \\
\hline & \multirow{2}{*}{\multicolumn{2}{|c|}{$\begin{array}{c}\text { No } \\
(n=103)\end{array}$}} & \multirow{2}{*}{\multicolumn{2}{|c|}{$\begin{array}{c}\text { Yes } \\
(n=16)\end{array}$}} & \multirow{3}{*}{$\begin{array}{c}p \\
0.262\end{array}$} \\
\hline & & & & & \\
\hline & 39 & $37.9 \%$ & 9 & $56.3 \%$ & \\
\hline Adrenaline > 0.1 & 5 & $4.9 \%$ & 2 & $12.5 \%$ & 0.523 \\
\hline Levonor & 16 & $15.5 \%$ & 2 & $12.5 \%$ & 0.952 \\
\hline IABP & 3 & $2.9 \%$ & 1 & $6.3 \%$ & 0.955 \\
\hline Bleeding & 4 & $3.9 \%$ & 1 & $6.3 \%$ & 0.818 \\
\hline pRBC administered intraoperatively & 0.92 & 1.48 & 1.81 & 1.80 & 0.021 \\
\hline pRBC outside the operating theater & 1.66 & 1.71 & 3.13 & 2.75 & 0.011 \\
\hline pRBC total & 2.58 & 2.55 & 4.94 & 3.89 & 0.002 \\
\hline Reoperation & 7 & $6.8 \%$ & 3 & $18.8 \%$ & 0.263 \\
\hline Ventilation time & 9.64 & 13.30 & 11.50 & 9.87 & 0.087 \\
\hline Reintubation & 0 & $0.0 \%$ & 0 & $0.0 \%$ & \\
\hline Tracheostomy & 0 & $0.0 \%$ & 0 & $0.0 \%$ & \\
\hline Renal replacement therapy & 1 & $1.0 \%$ & 0 & $0.0 \%$ & 0.282 \\
\hline Abdominal complications & 0 & $0.0 \%$ & 0 & $0.0 \%$ & \\
\hline Neurological complications & 4 & $3.9 \%$ & 2 & $12.5 \%$ & 0.395 \\
\hline Total complications & 10 & $9.7 \%$ & 4 & $25.0 \%$ & 0.177 \\
\hline
\end{tabular}

Type I neurological complications were included.

$I A B P$ - intra-aortic balloon pump, $p R B C-1$ unit of packed red blood cells

Tab. VII. Length of postoperative ward stay, length of hospital stay, and mortality in the study group after establishing the patient subgroup with baseline regional CNS saturation $<50 \%$

\begin{tabular}{lcccccc} 
& \multicolumn{5}{c}{ Baseline saturation $<50 \%$} \\
& \multicolumn{2}{c}{$\begin{array}{c}\text { No } \\
(n=103)\end{array}$} & & Yes \\
$(n=16)$ & & \\
Length of postoperative ward stay & 2.20 & 2.63 & 4.44 & 5.25 & 0.001 \\
\hline Length of hospital stay & 10.02 & 7.92 & 15.63 & 10.51 & 0.0005 \\
\hline Mortality & 1 & $1.0 \%$ & 0 & $0.0 \%$ & 0.282 \\
\hline
\end{tabular}

Sensitivity, specificity, and ROC curve analysis, combined with area under the curve calculation, indicate that the method has moderate differentiation properties (AUC $=$
0.78). The most useful cutoff value is $2496 \mathrm{~s}$, a time interval calculated with $66.7 \%$ sensitivity and $90.3 \%$ specificity (Fig. 1). 


\section{Discussion}

The aim of the intraoperative maintenance of the value of cerebral saturation $\left(\mathrm{ScO}_{2}\right)$ at the optimal level is to eliminate hypoperfusion and preserve positive oxygen balance in the CNS during the procedure [9]. It is expected that the use of this technique may limit the incidence of early neurological complications in patients after cardiac surgery procedures. The retrospective analysis conducted by Goldman et al. [10] indicated that the introduction of intraoperative cerebral oximetry monitoring combined with the use of a procedural algorithm in cases of desaturation decreased the incidence of postoperative strokes, limited the number of patients requiring prolonged lung ventilation, and shortened the time of hospitalization after heart procedures. Yao et al. [11] proved that a reduction of $\mathrm{ScO}_{2}$ to below $40 \%$ during procedures using extracorporeal circulation is associated with early postoperative dysfunction of the CNS. Slater et al. [12] confirm the higher incidence of cognitive impairment and longer hospitalization time in patients subject to longer durations of intraoperative cerebral desaturation. Hong et al. [13] did not document the relationship between NIRS monitoring and the incidence of cognitive impairment in patients after cardiac valve procedures. However, the authors confirm the longer hospitalization time in patients subject to intraoperative cerebral desaturation. They suggest treating $\mathrm{ScO}_{2}$ monitoring as a parameter representing systemic oxygen balance (index organ), as demonstrated by Murkin et al. [14] in their well-designed randomized study.

The authors of the latter study monitored regional CNS saturation, and, in the case of desaturation (a drop in saturation $>20 \%$ of the baseline value), they reacted with measures aimed at restoring the optimal blood oxygenation conditions in the CNS. It appears that the duration of cerebral desaturation was thus maximally shortened. No reduction in the incidence of neurological complications was demonstrated in the study group in comparison to the controls. The etiology of all registered strokes was ischemic. In accordance with the current guidelines, stroke is defined as new focal symptoms or a global neurological deficit persisting for more than 24 hours. The same definition applies to patients in the immediate postoperative period. A stroke diagnosed during the preparation for extubation is defined as an early stroke. The diagnosis of a delayed (deferred) stroke can be made if no neurological symptoms were observed immediately after extubation [15]. This type of complication occurs most frequently during the 3rd postoperative day. The development factors of the two types of complications vary. Independent factors of the occurrence of early stroke include generalized atherosclerosis, porcelain aorta, complex procedures, and long duration of extracorporeal circulation. The occurrence of delayed stroke is influenced by two types of risk factors: demographic and postoperative. It is worth noting that delayed stroke occurs more frequently in patients with unstable coronary artery disease. The most probable causes of the complication are believed to include the discontinuation of anticoagulants

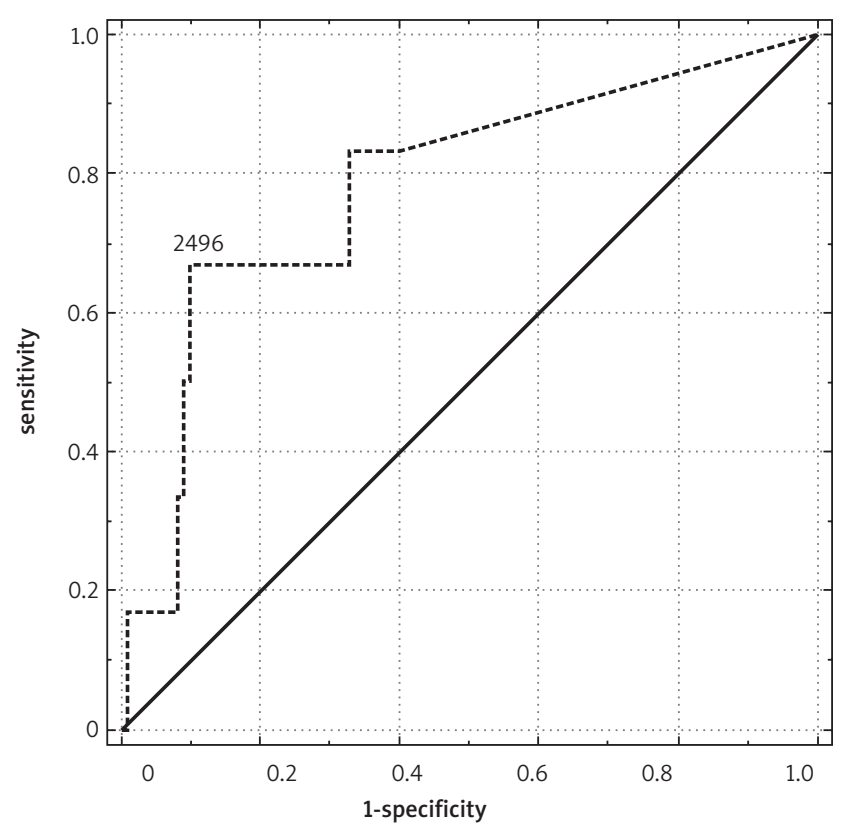

Fig. 1. ROC curve with the optimal cutoff value for the method. The area under the curve is 0.78

and the rebound effect during the early postoperative period involving the occurrence of thrombosis. In the opinion of the authors of the present study, the causes of delayed stroke may also include therapy improving blood coagulation parameters, introduced during the early postoperative period in patients with increased drainage (fresh frozen plasma, platelet concentrate, tranexamic acid). Taking the above into account and considering the cost of blood and blood products, we try to rationalize the transfusions performed at the postoperative ward, using a principle of targeted therapy, i.e. determining the parameters of the circulatory system and supplementing the lacking elements.

The documented causes of delayed stroke also include atrial fibrillation and low cardiac output syndrome during the early postoperative period requiring the prolonged use of catecholamines [16]. At one year after surgery, the expected lifespan of patients after early stroke is nearly identical to that of patients in whom no neurological complications occurred. The prognosis for patients after delayed stroke in whom the risk factors of neurological complications persist is different [15]. The present study analyzed the incidence of early stroke, which was demonstrated to be independent from the intraoperative values of brain oximetry. It is worth underscoring that the incidence of previous stroke, mean age, and operative risk, expressed as EuroSCORE values, were higher in the study group. It can, therefore, be surmised that the risk of intraoperative stroke was higher in the study group. It should, however, be noted that postoperative neurological complications also occur in patients with low or moderate preoperative risk of their occurrence [17].

The results of the conducted study confirm the reports by the authors cited above, pertaining to the improvement 
of the general organ function of patients in whom intraoperative monitoring was employed and cerebral saturation was maintained at the optimal level. The patients in the study group underwent ventilation for shorter periods of time than the controls. The frequency of using renal replacement therapy was comparable in both groups; however, the study group was characterized by a significantly higher incidence of chronic kidney disease before the procedure in comparison to the control group. Patients with low baseline cerebral saturation were transfused with a significantly higher number of packed red blood cell units in comparison to the remaining patients in the study group. The cardiac surgery ward uses restrictive criteria for blood transfusion. The criteria are relaxed in the case of unstable hemodynamic condition, prolonged mechanical lung ventilation, elevated lactate concentration, reduced venous blood saturation, or reduced mixed venous blood saturation. The presented results suggest a more severe clinical condition of the patients from the low baseline saturation group, even though the complication statistics do not confirm this. It appears that setting the functioning of implanted cardiac ventricles in accordance with cerebral oximetry indications is more efficacious than using continuous cardiac output measurements for the same purpose [18]. It can, therefore, be assumed that regional cerebral saturation constitutes an indication of systemic oxygen balance. All measures taken in order to optimize $\mathrm{ScO}_{2}$ have the same effect with regard to systemic tissue perfusion, resulting in a reduction of complications during the early postoperative period [14]. Monitoring $\mathrm{ScO}_{2}$ and preventing CNS desaturation provides a unique opportunity for preventing "silent" but potentially dangerous ischemia of other organs and tissues. Cerebral oximetry measurements are conducted with a non-invasive technique, and, in view of the presented facts, it may be used to substitute the invasive continuous monitoring of mixed venous blood saturation [19]. It should be stressed that no synchronous correlation has been found between cerebral desaturation events and lowered arterial blood saturation measured with pulse oximetry [20].

The ROC curve is a graphical representation of the compromise between sensitivity and specificity. The area under the curve (AUC) indicates that cerebral oximetry is a useful method for predicting neurological complications. The AUC value of 0.78 confirms moderate differentiation properties.

A low baseline value of $\mathrm{ScO}_{2}$ reflects significant impairment of circulatory system function and is associated with a complicated postoperative course. A baseline value of $\mathrm{ScO}_{2}$ $\leq 50 \%$ is an independent risk factor for short- and long-term mortality in patients after cardiac surgery procedures with the use of extracorporeal circulation [21]. The study did not demonstrate a more frequent incidence of postoperative complications in the group of patients with low baseline cerebral saturation, but it can be surmised that the patients were characterized by a more difficult course of the early postoperative period. Such conclusions are warranted by the significantly longer durations of hospital stay and postoperative ward stay observed in the group of patients with low baseline CNS saturation. It might be worth considering whether a low baseline value of $\mathrm{ScO}_{2}$ could be treated as an indication for extended hemodynamic monitoring during the intraoperative and postoperative period [22]. In the group with low baseline saturation, a significantly higher number of coronary artery bypass procedures was performed with the use of extracorporeal circulation. The reasons for adopting such a strategy most often include diffuse atherosclerosis and small coronary vessel size. Small coronary artery diameter is one of the cited causes of the worse results of coronary artery bypass procedures in women [23]. Our material did not reveal any predominance of female gender in the group of patients with low baseline saturation. However, it should be stressed that the group included only 16 patients.

One significant limitation of the study is the lack of cognitive impairment assessment and delirium analysis in both groups. The evaluation of cognitive function before surgery and before discharge is the domain of psychologists. It was not possible to organize the study in a way that would enable a psychological evaluation of cognitive function at two time points. Furthermore, the incidence of delirium was not assessed. In our ward, we do not employ the tools necessary for diagnosing the different types of delirium. We only diagnose its hyperactive form, and only this form is treated in a typical manner.

\section{Conclusions}

The patients from the $\mathrm{ScO}_{2}$ monitoring group were significantly older, and previous CNS strokes were more frequent in this group. Nevertheless, early postoperative strokes occurred with the same frequency in both groups. During the postoperative period, the patients in the study group required shorter lung ventilation and a lower number of packed red blood cell units. They were more often burdened with concomitant chronic kidney disease, which did not affect the frequency of employing renal replacement therapy during the postoperative period.

The obtained results corroborate the theory that the intraoperative maintenance of $\mathrm{ScO}_{2}$ at the optimal level protects organ function during the early postoperative period. However, confirming this hypothesis requires further study.

\section{References}

1. Korn-Lubetzki I, Oren A, Tauber R, Bitran D, Steiner-Birmanns B. No symptomatic intracerebral hemorrhage after cardiac surgery: A 14-year retrospective study. Eur Neurol 2010; 64: 351-354.

2. Carrascal Y, Guerrero AL. Neurological damage related to cardiac surgery pathophysiology, diagnostic ols and prevention strategies. Using actual knowledge for planning the future. Neurologist 2010; 16: 152-164.

3. Martin BJ, Buth KJ, Arora RC, Baskett RJF. Delirium as a predictor of sepsis in post-coronary artery bypass grafting patients: a retrospective cohort study. Critical Care 2010; 14: R171.

4. Rudolph JL, Schreiber KA, Culley DJ, McGlinchey RE, Crosby G, Levitsky S, Marcantonio ER. Measurement of post-operative cognitive dysfunction after cardiac surgery: a systematic review. Acta Anaesthesiol Scand 2010; 54: 663-677.

5. Erickson KM, Cole DJ. Carotid artery disease: stenting vs endarterectomy. $\mathrm{Br}$ J Anaesthesia 2010; 105: i34-i49. 
6. Vera R, Lago A, Fuentes B, Gállego J, Tejada J, Casado I, Purroy F, Delgado P, Simal P, Martí-Fábregas J, Vivancos J, Díaz-Otero F, Freijo M, Masjuan J, On behalf of the Stroke Project of the Spanish Cerebrovascular Diseases Study Group. In-hospital stroke: a multi-centre prospective registry. Eur J Neurol 2011; 18: 170-176.

7. Kimura K, Minematsu K, Yamaguchi T. Characteristics of in-hospital onset ischemic stroke. Eur Neurol 2006; 55: 155-159.

8. Kucewicz-Czech E, Urbańska E, Knapik P, Borkowski J, Podwińska E. Monitorowanie regionalnej saturacji mózgowej podczas zabiegów kardiochirurgicznych - algorytm postępowania. Kardiochir Torakochir Pol 2011; 8: 374 378.

9. Fischer GW. Recent advances in application of cerebral oximetry in adult cardiovascular surgery. Semin Cardiothorac Vasc Anesth 2008; doi: $10.1177 / 1089253208316443$.

10. Goldman S, Sutter F, Ferdinand F, Trace C. Optimizing intraoperative cerebral oxygen delivery using noninvasive cerebral oximetry decreases the incidence of stroke for cardiac surgical patients. Heart Surg Forum 2005; 7: E376-E381.

11. Yao FS, Tseng ChA, Ho ChA, Levin SK, Illner P. Cerebral oxygen desaturation is associated early postoperative neuropsychological dysfunction in patients undergoing cardiac surgery. J Cardiothorac Vasc Anesth 2004; 18 : 552-558.

12. Slater JP, Guarino T, Stack J, Vinod K, Bustami RT, Brown III JM, Rodriguez AL, Magovern ChJ, Zaubler T, Freundlich K, Parr GVS. Cerebral oxygen desaturation predicts cognitive decline and longer hospital stay after cardiac surgery. Ann Thorac Surg 2009; 87: 36-45.

13. Hong SW, Sim JK, Choi YS, Kim DH, Chang BCh, Kwak YL. Prediction of cognitive dysfunction and patients outcome following valvular heart surgery and the role of cerebral oximetry. Eur J Cardiothorac Surg 2008; 33: 560-565.

14. Murkin JM, Adams SJ, Novick RJ, Quantz M, Bainbridge D, Iglesias I, Cleland A, Schaefer B, Irwin B, Fox S. Monitoring brain oxygen saturation during coronary bypass surgery: a randomized, prospective study. Anesth Analg 2007; 104: 51-58.
15. Hedberg M, Boivie P, Engstrom KG. Early and delayed stroke after coronary surgery - an analysis of risk factors and the impact on short- and long-term survival. Eur J Cardiothorac Surg 2011; 40: 379-388.

16. Hogue Jr CW, Murphy SF, Schechtman KB, Davila-Roman VG. Risk factors for early or delayed stroke after cardiac surgery. Circulation 1999; 100: 642-647.

17. Likosky DS, Leavitt BJ, Marrin CA, Malenka DJ, Reeves AG, Weintraub RM, Caplan LR, Baribeau YR, Charlesworth DC, Ross CS, Braxton JH, Hernandez F Jr, O'Connor GT; Northern New England Cardiovascular Disease Study Group. Intra- and postoperative predictors of stroke after coronary artery bypass grafting. Ann Thorac Surg 2003; 76: 428-435.

18. Argiriadou H, Anastasiadis K, Antonitsis P, Karapanagiootidis G, Foroulis CN, Piggott D, Papakonstantinou C, Westaby S. Use of cerebral oximetry for monitoring cardiac output during off-pump implantation of Jarvic 2000 left ventricular assist device. Artif Organs 2010; 34: 267-271.

19. Paquet C, Deschamps A, Denault Ay, Couture P, Carrier M, Babin D, Levesque S, Piquette D, Lambert J, Tardif JC. Baseline regional cerebral saturation correlates with left ventricular systolic and diastolic function. J Cardiothorac Vasc Anesth 2008; 22: 840-846.

20. Casati A, Spreafico E, Putzu M, Fanelli G. New technology for noninvasive brain monitoring: continuous cerebral oximetry. Minerva Anestesiologica 2006; 72: 605-625.

21. Heringlake M, Garbers Ch, Kabler JH, Anderson I, Heinze H, Schon J, Berger KU, Dibbelt L, Sievers HH, Hanke T. Preoperative cerebral oxygen saturation and clinical outcomes in cardiac surgery. Anesthesiology 2011; 114: 58-69.

22. Murkin JM. Cerebral oximetry. Monitoring the brain as the index organ. Anesthesiology 2011; 114: 12-13.

23. Czech B, Kucewicz-Czech E, Pacholewicz J, Wojarski J, Puzio J, Przybylski R, Farmas A, Ryfiński B, Zembala M. Early results of coronary artery bypass graft surgery in women. Kardiol Pol 2007; 65: 627-633. 